\title{
High contribution of methane in greenhouse gas emissions from a eutrophic lake: a mass balance synthesis
}

Arianto B. Santoso ${ }^{* a c}$, David P. Hamilton ${ }^{\mathrm{b}}$, Louis A. Schipper ${ }^{\mathrm{c}}$, Ilia S.

Ostrovsky ${ }^{\mathrm{d}}$, and Chris H. Hendy ${ }^{\mathrm{c}}$

${ }^{a}$ Research Centre for Limnology, Indonesian Institute of Sciences, Bogor, Indonesia;

${ }^{b}$ Australian Rivers Institute, Griffith University, Nathan, Australia; ${ }^{c}$ Environmental

Research Institute, University of Waikato, Hamilton, New Zealand; ${ }^{d}$ Israel

Oceanographic \& Limnological Research, Yigal Alon Kinneret Limnological

Laboratory, Midgal, Israel

*corresponding author:

Arianto Budi Santoso, Research Centre for Limnology, Indonesian Institute of Sciences, Bogor 16911, Indonesia, email: ari@limnologi.lipi.go.id 


\title{
High contribution of methane in greenhouse gas emissions from a eutrophic lake: a mass balance synthesis
}

\author{
Lakes are 'hotspots' for greenhouse gas (GHG) emissions, primarily carbon \\ dioxide $\left(\mathrm{CO}_{2}\right)$ and methane $\left(\mathrm{CH}_{4}\right)$. Understanding the processes regulating $\mathrm{GHG}$ \\ emissions from lakes, and their temporal variability, is essential for more \\ accurately quantifying the role of lakes in global GHG cycles. In this study, we \\ identified the processes that affect $\mathrm{CO}_{2}$ and $\mathrm{CH}_{4}$ concentrations in a small $(0.3$ \\ $\mathrm{km}^{2}$ ) eutrophic monomictic lake (Okaro, New Zealand). A mass balance model \\ was used to calculate changes in $\mathrm{CO}_{2}$ and $\mathrm{CH}_{4}$ storage in the lake as a result of \\ internal cycling and atmospheric fluxes. To support model computations, $\mathrm{CO}_{2}$ \\ and $\mathrm{CH}_{4}$ concentrations profiles were measured monthly over a one-year period, \\ in addition to temperature, dissolved oxygen and chlorophyll $a$. Annually, Lake \\ Okaro acted as a sink of $\mathrm{CO}_{2}$ from the atmosphere (425.4 $\mathrm{mmol} \mathrm{CO}_{2} \mathrm{~m}^{-2} \mathrm{y}^{-1}$ ) and \\ a source of $\mathrm{CH}_{4}\left(553.4 \mathrm{mmol} \mathrm{CH}_{4} \mathrm{~m}^{-2} \mathrm{y}^{-1}\right)$ equating to a net $\mathrm{GHG}$ emission \\ (diffusive fluxes of $\mathrm{CO}_{2}$ and $\mathrm{CH}_{4}$ combined) of $0.22 \mathrm{~kg} \mathrm{CO}_{2}$-eq $\mathrm{m}^{-2} \mathrm{y}^{-1}$. Although \\ it may be viewed as conservative and applies only to diffusive fluxes, our study \\ indicates that eutrophic lakes with high rates of primary production may act as a \\ net source of GHGs.
}

Keywords: lake, eutrophic, greenhouse gas, $\mathrm{CO}_{2}, \mathrm{CH}_{4}$, thermal stratification.

\section{Introduction}

Inland waters (including ponds, lakes, wetlands, reservoirs, stream and rivers) are an important component of the global carbon balance (Cole et al. 2007; Tranvik et al. 2018; Bastviken et al. 2011) and important in the transfer of terrestrial carbon to the ocean (Aufdenkampe et al., 2011; Regnier et al., 2013). They cover $<3 \%$ of the Earth's surface (Downing et al., 2006) and emit about $0.8-2.1 \mathrm{Pg} \mathrm{C}^{-1}$ to the atmosphere as $\mathrm{CO}_{2}$ (Cole et al., 2007; Raymond et al., 2013; Regnier et al., 2013). These emissions are similar in magnitude to global $\mathrm{CO}_{2}$ atmospheric sinks of the open ocean $(1.85-2.6 \mathrm{Pg}$ $\left.\mathrm{C}^{-1}\right)$ and terrestrial systems (2.05 - 2.9 Pg C y ${ }^{-1}$ : Regnier et al., 2013; Le Quéré et al., 2015). Furthermore, Bastviken et al. (2011) estimated that $0.65 \mathrm{Pg} \mathrm{C} \mathrm{y}^{-1}$ is released to 
the atmosphere as $\mathrm{CH}_{4}$ from inland waters. Given that global warming potential of $\mathrm{CH}_{4}$ over a 100-year horizon is 34 times larger than that of $\mathrm{CO}_{2}$ (Myhre et al. 2013), inland waters are clearly highly important in global GHG emissions accounting.

Improvements in environmental sensor technology have enabled direct measurements of GHG emissions (e.g., Eugster et al. 2011; Gonzalez-Valencia et al. 2014). Together with more statistically robust upscaling techniques (Beaulieu et al. 2016; Wik et al. 2016), these advances have increased the accuracy of GHG emission estimates for inland waters. Better understanding of carbon processing by inland waters is essential, however, to improve GHG accounting (Hanson et al. 2015). Recent studies have shown that organic carbon processing in lakes, and the associated carbon emissions, are closely related to lake trophic status (Almeida et al. 2016; Santoso et al. 2017; Evans et al. 2017). Knowing that inland waters are dominated by small water bodies with surface area $<1 \mathrm{~km}^{2}$ (Messager et al. 2016), which are prone to eutrophication and high rates of organic carbon burial (Downing et al. 2008), small eutrophic lakes may make a significant contribution to global carbon budgets and climate change (Tranvik et al. 2018; Moss et al. 2011). Identification of the key parameters regulating eutrophication processes and GHG emissions from small lakes is therefore important to quantify these contributions.

Lakes with anoxic hypolimnia accumulate large quantities of $\mathrm{CH}_{4}$ and $\mathrm{CO}_{2}$ (Huttunen et al. 2003; Juutinen et al. 2009; López Bellido et al. 2009). In mono- and dimictic lakes, these stored gases can be released rapidly to the atmosphere during turnover periods (Fernández et al. 2014; Weyhenmeyer et al. 2015; Kankaala et al. 2007). Recent global estimates of $1.25-2.30 \mathrm{Pg}_{\mathrm{g}} \mathrm{CO}_{2}-\mathrm{eq} \mathrm{y}^{-1}$ from lakes and impoundments are nearly $20 \%$ of those from fossil fuels (DelSontro et al. 2018). Both $\mathrm{CO}_{2}$ and $\mathrm{CH}_{4}$ are highly important in contributing to $\mathrm{GHG}$ emissions from lakes, as well 
as $\mathrm{N}_{2} \mathrm{O}$, which is a more potent greenhouse gas also emitted from inland waters (Soued et al. 2016).

Eutrophication associated with greater productivity increases autotrophic fixation rates of $\mathrm{CO}_{2}$ (Davidson et al. 2015) but is also associated with higher respiration rates (Yvon-Durocher et al., 2010). Organic carbon processing in the sediment of productive lakes may produce substantial quantities of dissolved inorganic carbon and $\mathrm{CH}_{4}$ which, if subsequently exposed to the atmosphere, leads to high GHG emission (Bastviken et al. 2008; Walter et al. 2006). Previous estimates suggested that $\mathrm{CO}_{2}$ and $\mathrm{CH}_{4}$ contribute equally to the global warming potential of $\mathrm{GHG}$ emissions from lakes and impoundments (Tranvik et al. 2009; Bastviken et al. 2011). A recent synthesis, however, showed that eutrophic lakes release more $\mathrm{CH}_{4}$ to the atmosphere (DelSontro et al. 2018). Under future scenarios of increasing nutrient loads to inland waters, $\mathrm{CH}_{4}$ emissions from lakes and impoundments may substantially increase over the next century (Beaulieu et al. 2019).

Currently, estimates of $\mathrm{CO}_{2}$ and $\mathrm{CH}_{4}$ emissions from inland waters and their contributions to global warming potential are mainly based on statistical and upscaling methods (DelSontro et al. 2018; Beaulieu et al. 2019). Lack of detailed information on the interactions of biological and physical factors that affect the magnitude of the GHG fluxes limits the development of effective mitigation strategies to use in inland waters to combat global warming (Moss et al. 2011; Hamilton et al. 2013). Process based estimates could provide inexpensive alternatives in addressing ecosystem questions regarding the role of lakes in regulating carbon and GHG emissions (e.g. Hanson et al. 2004).

In this study, we applied a simple process-based mass balance model to a monomictic eutrophic lake to account for internal $\mathrm{CO}_{2}$ and $\mathrm{CH}_{4}$ cycling and the 
atmospheric fluxes of these gases. The model was calibrated with measurements of dissolved $\mathrm{CO}_{2}$ and $\mathrm{CH}_{4}$ concentration profiles. Through this model we estimate the proportion $\mathrm{CO}_{2}$ and $\mathrm{CH}_{4}$ emissions in the total emitted GHGs. We compare our estimates of carbon emissions from our study lake with a recent synthesis of carbon emissions from lakes globally (DelSontro et al. 2018). We also discuss the role of lakes in regulating GHGs and climate change (Moss et al. 2011), specifically in relation to the magnitude of emissions from productive eutrophic lakes.

\section{Methods}

\section{Study site}

The study site was Lake Okaro, $27 \mathrm{~km}$ south of Rotorua township, North Island of New Zealand (Figure 1). The lake is small $\left(0.32 \mathrm{~km}^{2}\right)$, with an average depth of $12.5 \mathrm{~m}$ (max. $18 \mathrm{~m}$ ) and is the most eutrophic of 12 major lakes in the Rotorua region. More than $90 \%$ of its catchment area $\left(3.98 \mathrm{~km}^{2}\right)$ is pasture used for dairy, deer, sheep and beef farming. Water residence time of Lake Okaro is estimated to be ca. 1.5 years, with surface inflows from two unnamed streams entering the lake from the north-west, and one outflow (Haumi Stream) in the south-east. The trophic state of this lake has increased since the 1960s (Forsyth et al. 1988) and is now considered eutrophic, with periodic blooms of cyanobacteria in spring and summer (Paul et al. 2008). The recorded chlorophyll a concentration ranged from 0.5 to $283 \mu \mathrm{g} \mathrm{L}^{-1}$ (Santoso et al. 2017). The hypolimnion of the lake is anoxic throughout most of the 9-month stratified period, from October to June (Özkundakci et al. 2011).

\section{The mass balance model}

A conceptual model was developed to calculate the whole-lake $\mathrm{CO}_{2}$ and $\mathrm{CH}_{4}$ fluxes and 
mass balance (Figure 2). The model was used to calculate changes in $\mathrm{CO}_{2}$ and $\mathrm{CH}_{4}$ stored in the lake due to 1) diffusion of $\mathrm{CO}_{2}$ and $\mathrm{CH}_{4}$ across the sediment-water interface, 2) atmospheric diffusive fluxes, 3) aerobic oxidation of $\left.\mathrm{CH}_{4}, 4\right)$ net $\mathrm{CO}_{2}$ uptake by phytoplankton, 5) phytoplankton decomposition, and 6) oxidation of dissolved organic carbon (DOC) (Table 1). The model assumed that lake sediment was the main source of $\mathrm{CO}_{2}$ and $\mathrm{CH}_{4}$. Phytoplankton respiration and decomposition, $\mathrm{CH}_{4}$ oxidation and DOC oxidation supply $\mathrm{CO}_{2}$ to the water column. Contributions of littoral aquatic plans to $\mathrm{CO}_{2}$ and $\mathrm{CH}_{4}$ storage in the lake were not included in the model as the depth limit for aquatic macrophytes ( 4.5 m: Vant et al. 1996) is around $6 \%$ of the lakebed area and macrophytes were observed only at low densities. Bubble dissolution associated with ebullition of $\mathrm{CH}_{4}$ from the lake sediment may contribute to the $\mathrm{CH}_{4}$ pool in the water column (Schmid et al. 2017) but this process was not included in the model due to: 1) the stochastic process of bubble production and release (Varadharajan and Hemond 2012), and 2) gas bubbles that may escape $\mathrm{CH}_{4}$ oxidation during transport to the water surface (DelSontro et al. 2010). Processes that may contribute to the wholelake $\mathrm{CO}_{2}$ and $\mathrm{CH}_{4}$ mass balance but were not conceptualized in the model are elaborated upon in the discussion.

The model was used to estimate changes in the whole-lake mass storage of $\mathrm{CO}_{2}$ and $\mathrm{CH}_{4}\left(\Delta \mathrm{CO}_{2}\right.$ and $\Delta \mathrm{CH}_{4}$ : Eqns 1 and 2, Table 1) based on the processes described above (see Eqns 3 to 8, Table 1). Assumptions used in the model are given in Table 2. The whole-lake mass storage was calculated as the total of $\mathrm{CO}_{2}$ and $\mathrm{CH}_{4}$ stored in $2 \mathrm{~m}$ depth intervals based on $\mathrm{CO}_{2}$ and $\mathrm{CH}_{4}$ concentrations in the layer and the hypsography of the lake.

The bottom sediment flux is the major source of GHG to the lake. Its dominance arises from high rates of remineralization of organic carbon accumulated in 
the bottom sediments (Kuivila et al. 1988). The sediment of Lake Okaro has been shown to remineralize carbon at a rate of $2.32 \mathrm{~mol} \mathrm{C} \mathrm{m}^{-2} \mathrm{y}^{-1}$, with $<0.01 \mathrm{~mol} \mathrm{C} \mathrm{m}^{-2} \mathrm{y}^{-1}$ in refractory form (Santoso et al. 2017). The carbon flux from the sediment to the water column was therefore estimated to be $6.35 \mathrm{mmol} \mathrm{C} \mathrm{m} \mathrm{m}^{-2}$. Up to $60 \%$ of this remineralized carbon may be dissolved inorganic carbon, while $40 \%$ may be $\mathrm{CH}_{4}$ (Klump et al. 2009). Data from Bastviken (2009) suggest that $\mathrm{CH}_{4}$ is oxidized to $\mathrm{CO}_{2}$ in the presence of DO, with an oxidation rate constant ( $\mathrm{K}_{\mathrm{CH} 4-\mathrm{O} 2}$; Table 2$)$ in the range $0.001-1.0 \mathrm{~d}^{-1}$, including in eutrophic lakes. We estimated the $\mathrm{CH}_{4}$ water column oxidation rate as a first order reaction following Lopes et al. (2011), with Arrhenius equation adjustment for water temperature (Eq. 5; Table 1) based on a $\mathrm{Q}_{10}$ temperature coefficient set to 2.2 (Bastviken 2009).

The model was used to calculate phytoplankton $\mathrm{CO}_{2}$ uptake (Up; Eq. 6, Table 1) as the difference between the volumetric rate of production and respiration, with respiration rate defined as a proportion of production ( $\mathrm{ra}$; Table 2). Cole et al. (2002) suggest that $85-90 \%$ of gross primary production (GPP) may be directly respired back through autotrophic respiration, while a lower range of $54-88 \%$ has been recorded previously (Quay et al. 1986). In this model we assigned a wider range of $r a$ value of 50 - 99\%. We estimated phytoplankton production using an empirical relationship based on chlorophyll a (Chl) concentration (del Giorgio and Peters 1993).

The high productivity of Lake Okaro contributes to its DOC pool. A strong tryptophan-like component of the DOC (Hartland, pers. comm. 2016) coincides with the presence of a deep chlorophyll maximum during stratification (Simmonds et al. 2015), which suggests that contributions from dead phytoplankton cells may dominate labile DOC in this layer. The $\mathrm{CO}_{2}$ production in this layer may therefore be significant. We assumed that $3 \%$ of phytoplankton production was exuded as refractory DOC (Hanson 
et al. 2004). We used a sensitivity analysis to test a wide range of mineralisation rates of extracellular labile DOC ( $r_{C h l}$ in Table $2 ; 0.1$ to $\left.70 \%\right)$. The extracellular DOC (Chllab; Eq. 7, Table 1) was assumed to decay rapidly in the surface layer to produce $\mathrm{CO}_{2}$ (Connolly and Coffin 1995). The remaining phytoplankton carbon production was considered to enter the particulate organic carbon pool and be subject to sedimentation to the bottom sediment.

Contributions of allochthonous DOC to the $\mathrm{CO}_{2}$ pool were assumed to be small. As residence time in Lake Okaro is 1.5 years, and considering that most DOC is from phytoplankton decay, we assumed that concentrations of DOC from the two streams were similar to those in the lake $\left(\sim 5.2 \mathrm{mg} \mathrm{L}^{-1}\right.$ : Bay of Plenty Regional Council, unpublished data), with a photo-oxidation rate ( $p x)$ of $0.005 \mathrm{~d}^{-1}$ (Hanson et al. 2004).

Gas exchange at the air-water interface was calculated using a boundary layer equation (Eq. 8; Table 1) with the gas exchange coefficient $\left(k_{\text {gas }}\right)$ estimated as a function of wind speed (Cole and Caraco 1998). Average monthly wind speed from the National Climate Database was used as input to the model. Due to uncertainty in gas transfer coefficient estimates (Raymond et al. 2013; Dugan et al. 2016), a correction factor (corrk; Table 2) was included in the gas exchange calculation for the purpose of sensitivity analysis. It was assumed that the atmospheric $\mathrm{CO}_{2}$ and $\mathrm{CH}_{4}$ concentrations were constant at $393.5 \mathrm{ppmv}$ and $1.76 \mathrm{ppmv}$, respectively.

As a soft water lake with low alkalinity of $\sim 0.6 \mathrm{meq} \mathrm{L}^{-1}$ (data not shown), inputs of inorganic carbon from carbonate weathering in Lake Okaro would likely be minor (Marcé et al. 2015). McColl (1972) noted that changes in $\mathrm{pH}$ in the surface waters are mostly regulated by phytoplankton productivity, while the reduced $\mathrm{pH}$ in the hypolimnion is related directly to $\mathrm{CO}_{2}$ production from decomposition in the tropholytic 
zone. Therefore, we assumed that changes in the whole-lake bicarbonate $\left(\mathrm{HCO}_{3}\right)$ mass occurred mostly from $\mathrm{CO}_{2}$ dissociation into the carbonate system.

An optimization routine was used to derive model parameter values which had ranges assigned based on those in the literature (Table 2). The optim() function with "L-BFGSB" method (R Core Team 2015) was applied. The routine minimized the residual errors between the modelled whole-lake gas storage (Eqns 3 and 4, Table 1) and the calculated gas storage from field observations (Eq. 2, Table 1).

An interpolation using a trapezoidal rule (R package Hmisc: Harrell 2015) was performed to calculate the annual whole-lake $\mathrm{CO}_{2}$ and $\mathrm{CH}_{4}$ mass, both for the observed and modeled mass balance. The modeled annual whole-lake value was calculated by summing the processes rates involved in the whole-lake carbon storage dynamics, i.e., diffusion across the sediment-water interface, aerobic $\mathrm{CH}_{4}$ oxidation, photosynthetic $\mathrm{CO}_{2}$ uptake, phytoplankton decay, DOC oxidation, and atmospheric flux over the period of observation. Finally, the total GHG emissions estimates $\left(\mathrm{kg} \mathrm{CO}_{2}\right.$-eq $\left.\mathrm{m}^{-2} \mathrm{y}^{-1}\right)$ were calculated as the sum of the modelled $\mathrm{CO}_{2}$ and $\mathrm{CH}_{4}$ atmospheric diffusive fluxes (Eq. 5) by multiplying each gas flux by its global warming potential (GWP) over a 100-year period (i.e., $\mathrm{CO}_{2}=1, \mathrm{CH}_{4}=34$; Myhre et al. 2013).

\section{Data collection}

To support model computation, we collected water column samples on a monthly basis from September 2013 to September 2014 from the deepest station of the lake (Figure 1). In mid-winter (June, southern hemisphere) additional samples were collected on two occasions to target changes in the water column profile due to the onset of a period of lake mixing each year. Water samples were collected at the subsurface $(0.5 \mathrm{~m})$ and to a depth of $16 \mathrm{~m}$ with a vertical resolution of $2 \mathrm{~m}$ using a 10-L Schindler-Patalas water 
sampler. Triplicate subsamples of $60 \mathrm{~mL}$ were taken from the sampler using a syringe, for dissolved $\mathrm{CO}_{2}$ and $\mathrm{CH}_{4}$ analysis. The aliquot in the syringe was transferred into a 45 $\mathrm{mL}$ glass bottle with excess water overflowing the bottle. The bottle was capped with a polypropylene screw cap with a silicon septum, leaving no bubbles in the bottle, and stored in the dark and cold $\left(4{ }^{\circ} \mathrm{C}\right)$ until analysis. Water column profiles of temperature and dissolved oxygen were taken on each sampling occasion using a conductivitytemperature-depth (CTD) profiler (Sea-Bird Electronics 19 plus) with an additional mounted dissolved oxygen (DO, Sea-Bird Electronics) sensor. We observed thermal stratification and the depth of the thermocline from the CTD temperature profiles and used the rLakeAnalyzer package (Winslow et al. 2015) to analyse metrics of mixing and stratification (see theoretical basis given by Read et al. 2011). Chlorophyll $a$ samples were collected as an integrated sample of the euphotic depth, from the immediate subsurface to a depth of approximately 2.4 times the average Secchi disk depth of $\sim 2.5$ m. Chlorophyll $a$ samples were analyzed by spectrophotometer following standard methods involving acetone extraction and correction for phaeophytin (APHA 1998).

Dissolved $\mathrm{CO}_{2}$ and $\mathrm{CH}_{4}$ concentrations for gas samples from the field were determined in the laboratory within $24 \mathrm{~h}$ of sampling using the headspace equilibration method (Striegl and Michmerhuizen 1998). Briefly, approximately $20 \mathrm{~mL}$ of pure $\mathrm{N}_{2}$ was injected into a $45 \mathrm{~mL}$ glass bottle through the silicon septum, replacing aliquots in the bottle to create headspace using a second needle to drain water. The remaining water volume in the bottle was kept at $28 \mathrm{~mL}$. Additional nitrogen gas $(5 \mathrm{~mL})$ was added to the bottles to over-pressurize the headspace in the bottle. Equilibration was performed by shaking the bottles vigorously for 3 minutes. Bottles were kept upside down to avoid gas leakage from the septa. Subsamples of $5 \mathrm{~mL}$ of equilibrated gas were transferred from the headspace into $3.7 \mathrm{~mL}$ pre-vacuumed Labco Exetainer ${ }^{\circledR}$ vials. The $\mathrm{CO}_{2}$ 
concentration in the headspace was measured by an infra-red gas analyser (IRGA, LICOR ${ }^{\circledR}$ LI-6262). A gas chromatograph equipped with a flame ionization detector (GCFID, Varian CP 3800) was used to determine $\mathrm{CH}_{4}$ concentrations in the headspace. The concentrations of dissolved gas in the water samples were then calculated based on the solubility function for $\mathrm{CO}_{2}$ and $\mathrm{CH}_{4}$ following Weiss and Price (1980) and Wiesenburg and Guinasso (1979), respectively.

\section{Uncertainty analysis}

Spatial heterogeneity may affect diffusive greenhouse estimates from lakes (Schilder et al. 2013, Beaulieu et al. 2016). As our data collection was focused on a central lake site in small, circular Lake Okaro, we therefore performed a bootstrapping procedure to determine the uncertainty in field measurements and provide some indication of spatial variability. For each measured data point, we created 1000 psuedodata points generated from a random normal distribution of the $15 \%$ deviation in the original measurement. We then fitted the mass balance model to the 1000 pseudo-data points to provide uncertainty estimates of model parameters. Through this bootstrapping procedure we were able to calculate the average and the $95 \%$ confidence interval of both, field measurement and model estimates. The performance of the model was tested by calculating the mean absolute error and Pearson correlation coefficient $(R)$ between simulation and observation.

\section{Results}

\section{Thermal stratification, dissolved oxygen and chlorophyll a concentration}

Between September 2013 and September 2014, Lake Okaro started to stratify around September 2013 (spring, southern hemisphere) and was completely mixed (i.e., isothermal) on 25 June 2014 (winter, Figure 3A). The thermocline was shallowest on 10 
October 2013 (3.1 m) and gradually increased in depth thereafter, until turnover. Surface water temperature increased steadily from $11.6^{\circ} \mathrm{C}$ (September) to a maximum of $23.4{ }^{\circ} \mathrm{C}$ (December, early summer) and continued to decrease gradually thereafter. Dissolved oxygen (DO) concentrations in the epilimnion were occasionally strongly supersaturated during stratification (126\% of saturation), while the concentration in the hypolimnion decreased rapidly with the onset of stratification (Figure 3B). The hypolimnion became anoxic $\left(<1 \mathrm{mg} \mathrm{L}^{-1}\right)$ from early summer. As the lake underwent seasonal mixing (end of May), the DO concentration was relatively low $\left(<5 \mathrm{mg} \mathrm{L}^{-1}\right)$ throughout water column before recovering to be close to saturation $\left(\sim 8 \mathrm{mg} \mathrm{L}^{-1}\right)$ after a period of sustained mixing (late Jun-Jul). Chl concentrations peaked $\left(>50 \mu \mathrm{g} \mathrm{L}^{-1}\right)$ in August - October (spring) at the onset of thermal stratification but were consistently lower (mean $14.6 \mu \mathrm{g} \mathrm{L}^{-1}$ ) during the latter period of stratification from December to June.

\section{$\mathrm{CO}_{2}$ and $\mathrm{CH}_{4}$ concentrations and storage dynamics}

During the stratification period (September to May), concentrations of dissolved $\mathrm{CO}_{2}$ and $\mathrm{CH}_{4}$ in the epilimnion were mostly low, $<1-15.4 \mu \mathrm{mol} \mathrm{L}-1$ and $0.1-1.4 \mu \mathrm{mol} \mathrm{L}^{-1}$, respectively (Figures 3C and 3D). In contrast, concentrations in the hypolimnion were relatively high, reaching $>230$ and $>240 \mu \mathrm{mol} \mathrm{L}^{-1}$ for $\mathrm{CO}_{2}$ and $\mathrm{CH}_{4}$, respectively. While hypolimnetic $\mathrm{CO}_{2}$ concentrations started to increase immediately following the depletion of DO in the hypolimnion (late September), $\mathrm{CH}_{4}$ concentrations increased later (mid-January), as the bottom waters became anoxic. The highest bottom-water (16m depth) concentrations of $\mathrm{CO}_{2}$ and $\mathrm{CH}_{4}$ occurred just before turnover, in May. On 27 May 2014, epilimnetic $\mathrm{CO}_{2}$ and $\mathrm{CH}_{4}$ concentrations were high $\left(43.4-52.7 \mu \mathrm{mol} \mathrm{L}^{-1}\right.$ and $6.5-19.9 \mu \mathrm{mol} \mathrm{L}^{-1}$, respectively). Just after the onset of turnover (end of May to early June), concentrations of $\mathrm{CO}_{2}$ and $\mathrm{CH}_{4}$ were relatively uniform through the water 
column at $93.0-102.4 \mu \mathrm{mol} \mathrm{L}{ }^{-1}$ and $15.6-20.0 \mu \mathrm{mol} \mathrm{L}^{-1}$, respectively.

The dynamics of $\mathrm{CO}_{2}$ and $\mathrm{CH}_{4}$ concentrations reflect the temporal variations of storage in the lake (Figures $4 \mathrm{~A}$ and $4 \mathrm{~B}$ ). Whole-lake $\mathrm{CO}_{2}$ mass was calculated to be low $\left(63.0 \mathrm{mmol} \mathrm{CO}_{2} \mathrm{~m}^{-2}\right)$ when the lake started to stratify in September (Figure 4A). The mass initially increased gradually, at rate of $3.4 \mathrm{mmol} \mathrm{CO}_{2} \mathrm{~m}^{-2} \mathrm{~d}^{-1}$ as stratification developed in September (Figure 4C), and had increased abruptly to $63.1 \mathrm{mmol} \mathrm{CO}_{2} \mathrm{~m}^{-2}$ $\mathrm{d}^{-1}$ at turnover (late May to early June), yielding whole-lake $\mathrm{CO}_{2}$ storage of $1412 \mathrm{mmol}$ $\mathrm{CO}_{2} \mathrm{~m}^{-2}$ (Figure 4A). Soon after, in late June, $\mathrm{CO}_{2}$ decreased rapidly from the lake, at a rate of $50.3 \mathrm{mmol} \mathrm{m}^{-2} \mathrm{~d}^{-1}$ (Figure $4 \mathrm{C}$ ). This $\mathrm{CO}_{2}$ loss continued until the end of August, but at a decreased rate of $1.6 \mathrm{mmol} \mathrm{m}^{-2} \mathrm{~d}^{-1}$ when the whole-lake $\mathrm{CO}_{2}$ mass was 53.0 mmol $\mathrm{CO}_{2} \mathrm{~m}^{-2}$ (Figure $4 \mathrm{~A}$ ). Accumulation of $\mathrm{CH}_{4}$ in bottom waters started later than $\mathrm{CO}_{2}$, in late December, at a rate ca. $2.6 \mathrm{mmol} \mathrm{m}^{-2} \mathrm{~d}^{-1}$ (Figure 4D), after the lake has been stratified for some time (Figure 4B) and then increased abruptly, at a rate of 19.0 mmol $\mathrm{CH}_{4} \mathrm{~d}^{-1}$ (Figure 4D) through mid-April. By this time the whole-lake $\mathrm{CH}_{4}$ storage was $723 \mathrm{mmol} \mathrm{m}^{-2}$ (Figure 4B). As the thermocline deepened nearing the end of summer stratification (late May), the accumulated $\mathrm{CH}_{4}$ in the lake started to decline. The rate of loss of $\mathrm{CH}_{4}$ was calculated to be $7.4 \mathrm{mmol} \mathrm{m}^{-2} \mathrm{~d}^{-1}$ and was maximal at 18.8 mmol $\mathrm{m}^{-2} \mathrm{~d}^{-1}$ during prior to or during turnover (early June, Figure 4D). During the remaining period of mixing (June - August), however, $\mathrm{CH}_{4}$ loss was reduced to $<0.1$ mmol m $\mathrm{m}^{-2} \mathrm{~d}^{-1}$, leaving only $2.3 \mathrm{mmol} \mathrm{CH}_{4} \mathrm{~m}^{-2}$ in the lake by the end of August.

\section{Mass balance model output and $\mathrm{CO}_{2}$ and $\mathrm{CH}_{4}$ internal cycling}

An optimization procedure (see Methods) was used to calibrate parameters in the mass balance model. Performance statistics for the mass balance model comparisons against measured $\mathrm{CO}_{2}$ and $\mathrm{CH}_{4}$ storages were satisfactory. The mean absolute error was low for 
comparisons of $\Delta \mathrm{CO}_{2}$ and $\Delta \mathrm{CH}_{4}$ in the model against field observations $(3.10 \mathrm{mmol}$ $\mathrm{CO}_{2} \mathrm{~m}^{-2} \mathrm{~d}^{-1}$ and $\left.2.66 \mathrm{mmol} \mathrm{CH}_{4} \mathrm{~m}^{-2} \mathrm{~d}^{-1}\right)$ and the correlation coefficient $(R)$ was 0.933 and 0.831 for $\Delta \mathrm{CO}_{2}$ and $\Delta \mathrm{CH}_{4}$, respectively.

Most of the time the lake acted as a sink for $\mathrm{CO}_{2}$, except during the onset of seasonal mixing in May to early June when atmospheric emissions were highly variable (Figure 5A). In the early stages of thermal stratification (September), there was a large influx of atmospheric $\mathrm{CO}_{2}$, calculated to be $15.12 \mathrm{mmol} \mathrm{CO}_{2} \mathrm{~m}^{-2} \mathrm{~d}^{-1}$. In early June, however, emissions were calculated to be $60.85 \mathrm{mmol} \mathrm{CO}_{2} \mathrm{~m}^{-2} \mathrm{~d}^{-1}$ to the atmosphere. Over the entire period of the study, we calculated that Lake Okaro took up $\mathrm{CO}_{2}$ at a rate of $452.4 \mathrm{mmol} \mathrm{m}^{-2} \mathrm{y}^{-1}$ from the atmosphere.

The annual water column $\mathrm{CO}_{2}$ utilization by phytoplankton photosynthetic uptake was calculated to be up to $4950.4 \mathrm{mmol} \mathrm{m}^{-2} \mathrm{y}^{-1}$ (Table 3), with the highest uptake during spring (August to October) of $\sim 30 \mathrm{mmol} \mathrm{CO}_{2} \mathrm{~m}^{-2} \mathrm{~d}^{-1}$ (Figure 5B). Decay of phytoplankton was estimated to release $2974.4 \mathrm{mmol} \mathrm{CO}_{2} \mathrm{~m}^{-2} \mathrm{y}^{-1}$ to the lake (Table 3). The calculated $\mathrm{CO}_{2}$ sediment diffusion flux to the water column was $1430.2 \mathrm{mmol} \mathrm{m}^{-2}$ $\mathrm{y}^{-1}$ and the DOC oxidation was calculated to add $175.0 \mathrm{mmol} \mathrm{m}^{-2} \mathrm{y}^{-1}$ of $\mathrm{CO}_{2}$ to the water column $\mathrm{CO}_{2}$ pool.

$\mathrm{CH}_{4}$ was calculated to be continuously lost diffusively from the lake water surface to the atmosphere at low levels $\left(\sim 1 \mathrm{mmol} \mathrm{CH}_{4} \mathrm{~m}^{-2} \mathrm{~d}^{-1}\right)$, except during the onset of mixing when emissions peaked at $9.95 \mathrm{mmol} \mathrm{CH}_{4} \mathrm{~m}^{-2} \mathrm{~d}^{-1}$ (Figure 5C). Annually, this atmospheric flux was calculated to be $553.4 \mathrm{mmol} \mathrm{CH}_{4} \mathrm{~m}^{-2} \mathrm{y}^{-1}$ (Table 3). Sediment diffusion flux of $\mathrm{CH}_{4}$ to the lake water column was calculated to be $946.0 \mathrm{mmol} \mathrm{m}^{-2} \mathrm{y}^{-1}$ (Table 3). The accumulated $\mathrm{CH}_{4}$ in the whole water column was estimated to undergo oxidation at a rate of $508.5 \mathrm{mmol} \mathrm{m}^{-2} \mathrm{y}^{-1}$. The highest $\mathrm{CH}_{4}$ oxidation rate occurred during mixing in late May, at $10.8 \mathrm{mmol} \mathrm{m}^{-2} \mathrm{~d}^{-1}$ (Figure 5D). $\mathrm{CH}_{4}$ is assumed to be 
oxidized to $\mathrm{CO}_{2}$ in the water column, equating to $508.5 \mathrm{mmol} \mathrm{CO}_{2} \mathrm{~m}^{-2} \mathrm{y}^{-1}$ annually (Table 3).

\section{Greenhouse gas emissions}

Based on our mass balance calculation, Lake Okaro was considered at annual time scales to be a sink of $\mathrm{CO}_{2}$ from the atmosphere and a source of $\mathrm{CH}_{4}$ (Table 3). Translated into the global warming potential of these emissions, the lake is a sink for $5.6 \times 10^{-3} \mathrm{~kg} \mathrm{CO}_{2}$-eq $\mathrm{m}^{-2} \mathrm{y}^{-1}$ from the atmosphere and releases $226.0 \times 10^{-3} \mathrm{~kg} \mathrm{CO}_{2}$-eq $\mathrm{m}^{-2} \mathrm{y}^{-1}$. The net result of these GHG fluxes was estimated to be $222.6 \times 10^{-3} \mathrm{~kg} \mathrm{CO}_{2}$-eq $\mathrm{m}^{-2} \mathrm{y}^{-1}$

\section{Discussion}

\section{$\mathrm{CO}_{2}$ and $\mathrm{CH}_{4}$ dynamics and the mass balance model}

The dynamics of dissolved $\mathrm{CO}_{2}$ and $\mathrm{CH}_{4}$ for the lake in this study were strongly seasonally dependent. The observed pattern is similar to observations in other monomictic and dimictic lakes, with at least four distinct periods (Striegl and Michmerhuizen 1998; Riera et al. 1999; López Bellido et al. 2011). These periods relate to (1) dissolved gas $\left(\mathrm{CO}_{2}\right.$ and $\left.\mathrm{CH}_{4}\right)$ accumulation in the hypolimnion as stratification begins in spring, (2) high concentrations of dissolved gas in the hypolimnion and low concentrations in the surface layer during summer stratification, (3) high dissolved gas concentrations in the surface layer, as well as high atmospheric fluxes at the onset of breakdown of stratification in autumn, and (4) rapid loss of dissolved gases in the surface water during the period of turnover. Progressive deepening of the thermocline gradually entrained $\mathrm{CO}_{2}$ and $\mathrm{CH}_{4}$ from the hypolimnion into surface waters prior to complete water column mixing. When fully mixed, there was complete entrainment of 
the highly enriched (with $\mathrm{CO}_{2}$ and $\mathrm{CH}_{4}$ ) remaining hypolimnetic waters with the surface waters, yielding major gas releases to the atmosphere (Fig. 3C, 3D, 5A and 5C).

While direct measurements of carbon emissions have been improved in recent times, processes involved in the genesis, accumulation and release of greenhouse gases are still difficult to monitor in natural aquatic ecosystems. The mass balance model used in this study was fed by monitoring data and utilized parameters from the literature to address gaps in monitoring fluxes, allowing a comparison of the relative magnitude of the major processes that contribute to the fluxes of $\mathrm{CO}_{2}$ and $\mathrm{CH}_{4}$. The model performed well in simulating changes in the whole-lake mass storage of $\mathrm{CO}_{2}$ and $\mathrm{CH}_{4}($ Figure $4 \mathrm{C}$ and 4D). The model can be used to differentiate contributions of different processes that regulate loss and gain of $\mathrm{CO}_{2}$ and $\mathrm{CH}_{4}$ in the water column (see Figure 2), but uncertainties exist with model parameters (Figure 4C and 4D) that, based on sensitivity analysis, could be prioritised for further study.

Based on our model, we calculated that a large proportion of $\mathrm{CO}_{2}$ was taken up by phytoplankton, consistent with the lake trophic state classification of eutrophic (Table 3). This high $\mathrm{CO}_{2}$ demand was balanced by inputs from the sediment, atmospheric exchange, phytoplankton decomposition, DOC oxidation and $\mathrm{CH}_{4}$ oxidation. Assuming that phytoplankton uptake results in loss of carbon to the sediments as the resulting organic material sediments out (and after subtracting water column losses of $\mathrm{CO}_{2}$ to decomposition), the annual sedimentary carbon addition is estimated to be $2087.4 \mathrm{mmol} \mathrm{C} \mathrm{m}^{-2}$. This estimate is slightly lower our earlier prediction (2320 mmol $\mathrm{C} \mathrm{m}^{-2} \mathrm{y}^{-1}$ ) calculated using a first order diagenesis model for labile organic matter in lake sediment cores (Santoso et al. 2017). Some factors influencing lake $\mathrm{CO}_{2}$ storages were not accounted for in the model, e.g., stream organic and inorganic carbon (Weyhenmeyer et al. 2015; Maberly et al. 2013; Wilkinson et al. 2016). These potential 
sources of error are likely to have made only a small contribution to the lake $\mathrm{CO}_{2}$ pool (see Figure 4C).

Through the model, we estimated that, on an annual basis, $\sim 63 \%$ of $\mathrm{CH}_{4}$ produced by the sediment (as diffusive flux) is oxidized to $\mathrm{CO}_{2}$, resulting in reduced fluxes of $\mathrm{CH}_{4}$ to the atmosphere (Table 3 ). There is considerable debate about the extent that oxidation reduces $\mathrm{CH}_{4}$ emissions (Schubert et al. 2012; Fernández et al. 2014) and this uncertainty complicates global estimates of GHG emission potential from lakes, particularly from those that are eutrophic. In our model the fraction of $\mathrm{CH}_{4}$ released to the atmosphere exceeded the residual component of sediment production and water column oxidation (Table 3). The $\mathrm{CH}_{4}$ ebullition not accounted for may have influenced both $\mathrm{CH}_{4}$ and $\mathrm{CO}_{2}$ storages in the lake. As $\mathrm{CH}_{4}$ bubbles rise following release from the sediment, a large proportion of the $\mathrm{CH}_{4}$ dissolves into surrounding water medium (McGinnis et al. 2006; Ostrovsky et al. 2008). Some may be oxidized to $\mathrm{CO}_{2}$, especially in the presence of dissolved oxygen that is usually present at levels close to saturation in the upper mixed stratum (Schmid et al. 2017), while a large proportion ( $>80 \%)$ may escape oxidation and be released to the atmosphere (DelSontro et al. 2010; Martinez and Anderson 2013). West et al. (2016) estimated that sediments in shallow areas $(<6 \mathrm{~m}$ depth) of productive lakes may produce $\mathrm{CH}_{4}$ at a rate of ca. $24 \mathrm{mmol} \mathrm{m}^{-2} \mathrm{~d}^{-1}$. This methane production coincided with high probability of emission from ebullition. Using these estimates, we can conservatively calculate $\mathrm{CH}_{4}$ emission via ebullition. Assuming that the shallow zone of Lake Okaro is $6 \%$ of the total surface area (see Methods), methane production in the shallow zone is $1.44 \mathrm{mmol} \mathrm{CH}_{4} \mathrm{~m}^{-2} \mathrm{~d}^{-1}$ which equates to an annual production of $525.6 \mathrm{mmol} \mathrm{CH}_{4} \mathrm{~m}^{-2} \mathrm{y}^{-1}$. Accordingly, $108.0 \mathrm{mmol} \mathrm{m}^{-2} \mathrm{y}^{-1}$ may have dissolved in the water column, balancing the $\mathrm{CH}_{4}$ pool in the lake, while 417.6 mmol m $\mathrm{m}^{-2} \mathrm{y}^{-1}$ may have escaped to the atmosphere through ebullition. However, as our 
model did not incorporate $\mathrm{CH}_{4}$ ebullition due to its stochastic nature (Varadharajan and Hemond 2012), estimates of carbon emissions from Lake Okaro in this study should be viewed as conservative and apply only to diffusive fluxes of $\mathrm{CO}_{2}$ and $\mathrm{CH}_{4}$. Thus, as fluxes may vary spatially and temporally (e.g. Schilder et al. 2013; Beaulieu et al. 2016), better quantification and resolution of both diffusive and ebullitive fluxes are an important prerequisite for high precission estimates of carbon emissions from lakes.

\section{GHG emissions from eutrophic lakes}

Moss et al. (2011) noted that eutrophication may promote climate change. Productive eutrophic lakes, indicated by elevated levels of chlorophyll $a$, may store more carbon in the sediment than less productive lakes (Santoso et al. 2017; Sobek 2009). Remineralization of the deposited carbon produces dissolved organic and inorganic carbon as well as $\mathrm{CO}_{2}$ and $\mathrm{CH}_{4}$, which can re-enter the water column and may ultimately contribute to GHG emissions (Klump et al. 2009).

We compared our estimates of GHG emissions from Lake Okaro, computed from the mass balance model, with lakes across a range of trophic state gradients. Emissions from diffusive fluxes of $\mathrm{CO}_{2}$ and $\mathrm{CH}_{4}$ (converted to $\mathrm{kg} \mathrm{CO}_{2}$-eq $\mathrm{m}^{-2} \mathrm{y}^{-1}$ ), together with chlorophyll $a$ concentrations $(\mathrm{n}=316)$, are available for lakes across the globe from Downing et al. (2018). Trophic states of these lakes were defined based on chlorophyll $a$ concentration following Nürnberg (1996) where $\leq 3.5 \mu \mathrm{g} \mathrm{L}^{-1}$ is classified as oligotrophic, $>3.5 \mu \mathrm{g} \mathrm{L}^{-1}$ and $\leq 9 \mu \mathrm{g} \mathrm{L}^{-1}$ is mesotrophic, and $>9 \mu \mathrm{g} \mathrm{L}^{-1}$ is eutrophic. It was shown that chlorophyll a concentration was positively correlated with GHG emissions, although the statistical fit was modest (Figure 6). Results from Lake Okaro and global lakes imply that eutrophic lakes tend to have higher greenhouse gas emissions than oligo- and mesotrophic lakes. Our results reinforce recent syntheses that 
conclude that productivity is an important factor in scaling the magnitude of GHG emissions from lakes (DelSontro et al. 2018).

The ratios of $\mathrm{CO}_{2}$ and $\mathrm{CH}_{4}$ in the total annual $\mathrm{GHG}$ emissions are varied across lake trophic gradient (Figure 7, also see density distribution of the data in Supplementary Information). Most eutrophic lakes release more $\mathrm{CH}_{4}$ than $\mathrm{CO}_{2}$, with ratios ca. 0.8. Oligo- and mesotrophic lakes tend to release more $\mathrm{CO}_{2}$ than $\mathrm{CH}_{4}$ with ratios of 2.4 and 1.2, respectively. Lake Okaro, on the other hand, released $100 \% \mathrm{CH}_{4}$, and received only a very small input of $\mathrm{CO}_{2}$ (Figure 7). These results emphasize that $\mathrm{CH}_{4}$ is the major contributor of emissions from eutrophic lakes. This study focused on diffusive fluxes only but emissions due to ebullition (mainly $\mathrm{CH}_{4}$ ) from lakes and impoundments can be substantial and are often larger in small and shallow systems (Holgerson and Raymond 2016; Martinez and Anderson 2013) as well as in productive systems (DelSontro et al. 2018). High algal biomass in eutrophic systems may enrich the sediments with autochthonous carbon which is more labile and readily converted to $\mathrm{CH}_{4}$ than allochthonous carbon, which tends to be more recalcitrant (West et al. 2012).

As eutrophication of inland waters is ongoing, and despite concerted efforts to thwart it (Smith et al. 2014), inland waters will probably be one of the main actors in enhancing global warming through $\mathrm{CH}_{4}$ emissions (see Beaulieu et al. 2019). Knowing that inland waters are dominated by small lakes with surface areas of $<1 \mathrm{~km}^{2}$ (Downing et al. 2006) and are prone to eutrophication, as well as having high areal rates of organic carbon burial (Downing et al. 2008), lake restoration may be used as an important mitigation strategy to combat global warming.

\section{Conclusions}

This study demonstrated that $\mathrm{CO}_{2}$ and $\mathrm{CH}_{4}$ emissions in monomictic eutrophic lakes are 
driven by an interplay between seasonal thermal stratification and biological processes (i.e., organic carbon mineralization, phytoplankton uptake and decay, and $\mathrm{CH}_{4}$ oxidation). Through a mass balance model, we showed that productive eutrophic Lake Okaro has a net release of $\mathrm{CH}_{4}$ that exceeds its uptake of $\mathrm{CO}_{2}$ from the atmosphere, both in magnitude and more so in terms of GHG warming potential. This analysis may be viewed as conservative and applies only to diffusive fluxes, however it underscores that $\mathrm{CH}_{4}$ emissions from eutrophic lakes are strongly influenced by eutrophication. As eutrophic lakes emit more greenhouse gases, we suggest that lake restoration should be considered as part of a mitigation strategy to combat global warming.

\section{Acknowledgement}

We thank the Bay of Plenty Regional Council (BOPRC) for technical support, and Paul Scholes of BOPRC for data provision. Special thanks to Joseph Butterworth (BOPRC) for field work assistance and Janine Ryburn (The University of Waikato) for helpful support in laboratory analysis.

\section{Disclosure statement}

The author(s) declare(s) that there is no conflict of interest regarding the publication of this article.

\section{Author contributions}

ABS: Conceptualization, Methodology, Software, Validation, Formal Analysis, Investigation, Writing - Original Draft, Writing - Reviewing and Editing,

DPH: Funding acquisition, Supervision, Resources, Writing - Reviewing and Editing.

LAS: Supervision, Resources, Reviewing and Editing.

ISO: Writing - Reviewing and Editing. 
CHH: Supervision.

\section{Funding}

This study was part of a PhD project supported by the NZ-ASEAN Scholarship.

Research funding for this study was also supported through the Lake Biodiversity Restoration programme funded by the Ministry of Business, Innovation \& Employment (UOWX0505) and the Bay of Plenty Chair in Lake Restoration at the University of Waikato.

\section{References}

Almeida RM, Nóbrega GN, Junger PC, Figueiredo A V., Andrade AS, de Moura CGB, Tonetta D, Oliveira ES, Araújo F, Rust F, et al. 2016. High primary production contrasts with intense carbon emission in a eutrophic tropical reservoir. Frontiers in Microbiology. 7(MAY):1-13.

APHA. 1998. Standard methods for the examination of water and wastewater. 20th ed. Washington, D.C. APHA-AWWA-WEF.

Aufdenkampe AK, Mayorga E, Raymond PA, Melack JM, Doney SC, Alin SR, Aalto RE, Yoo K. 2011. Riverine coupling of biogeochemical cycles between land, oceans, and atmosphere. Frontiers in Ecology and the Environment. 9(1):53-60.

Bastviken D, Cole JJ, Pace ML, Van de-Bogert MC. 2008. Fates of methane from different lake habitats: Connecting whole-lake budgets and $\mathrm{CH}_{4}$ emissions. Journal of Geophysical Research. 113(2):1-13. 
Bastviken D, Tranvik LJ, Downing JA, Crill PM, Enrich-Prast A. 2011. Freshwater

Methane Emissions Offset the Continental Carbon Sink. Science (80- ). 331(6013):50.

Bastviken D. 2009. Methane. In: Likens GE, editor. Encycl Inland Waters. Oxford: Academic Press; p. 783-805.

http://www.sciencedirect.com/science/article/pii/B9780123706263001174

Beaulieu JJ, DelSontro T, Downing JA. 2019. Eutrophication will increase methane emissions from lakes and impoundments during the 21 st century. Nature Communications. 10(1):3-7. http://dx.doi.org/10.1038/s41467-019-09100-5

Beaulieu JJ, McManus MG, Nietch CT. 2016. Estimates of reservoir methane emissions based on a spatially balanced probabilistic-survey. Limnology and Oceanography. 61:S27-S40.

Cole JJ, Caraco NF. 1998. Atmospheric exchange of carbon dioxide in a low-wind oligotrophic lake measured by the addition of SF6. Limnology and Oceanography. 43(4):647-656.

Cole JJ, Carpenter SR, Kitchell JF, Pace ML. 2002. Pathways of organic carbon utilization in small lakes: Results from a whole-lake 13C addition and coupled model. Limnology and Oceanography. 47(6):1664-1675.

Cole JJ, Prairie YT, Caraco NF, McDowell WH, Tranvik LJ, Striegl RG, Duarte CM, Kortelainen P, Downing JA, Middelburg JJ, Melack J. 2007. Plumbing the global carbon cycle: Integrating inland waters into the terrestrial carbon budget. Ecosystems. 10(1):171-184.

Connolly JP, Coffin RB. 1995. Model of carbon cycling in planktonic food webs. Journal of Environmental Engineering. 121(10):682-690. 
Davidson TA, Audet J, Svenning JC, Lauridsen TL, Søndergaard M, Landkildehus F, Larsen SE, Jeppesen E. 2015. Eutrophication effects on greenhouse gas fluxes from shallow-lake mesocosms override those of climate warming. Global Change Biology. 21(12):4449-4463.

del Giorgio PA, Peters RH. 1993. Balance between Phytop ankton Produdion and P Respiration in Lakes. Canadian Journal of Fisheries and Aquatic Science. 50:282-289.

DelSontro T, Beaulieu JJ, Downing JA. 2018. Greenhouse gas emissions from lakes and impoundments: Upscaling in the face of global change. Limnology and Oceanography Letters: 64-75. http://doi.wiley.com/10.1002/lol2.10073

DelSontro T, McGinnis DF, Sobek S, Ostrovsky I, Wehrli B. 2010. Extreme Methane Emissions from a Swiss Hydropower Reservoir: Contribution from Bubbling Sediments. Environmental Science \& Technology. 44(7):2419-2425. http://dx.doi.org/10.1021/es9031369

Downing J, Beaulieu J, DelSontro T. 2018. DelSontro, Beaulieu \& Downing- files for SI- Greenhouse gas emissions from lakes and impoundments: upscaling in the face of global change. Limnology and Oceanography Letters doi: 10.1002/lol2.10073. https://figshare.com/articles/dataset/DelSontro_Beaulieu_Downing-_files_for_SIGreenhouse gas emissions from lakes and impoundments upscaling in the face of global_change CONFIDENTIAL-_FOR_REVIEW PURPOSES_ONLY /5220001

Downing JA, Cole JJ, Middelburg JJ, Striegl RG, Duarte CM, Kortelainen P, Prairie YT, Laube KA. 2008. Sediment organic carbon burial in agriculturally eutrophic impoundments over the last century. Global Biogeochemical Cycles. 22(1):1-10.

Downing JA, Prairie YT, Cole JJ, Duarte CM, Tranvik LJ, Striegl RG, McDowell WH, Kortelainen P, Caraco NF, Melack JM. 2006. The global abundance and size 
distribution of lakes, ponds, and impoundments. Limnology and Oceanography. 51(5):2388-2397.

Dugan HA, Iestyn Woolway R, Santoso AB, Corman JR, Jaimes A, Nodine ER, Patil VP, Zwart JA, Brentrup JA, Hetherington AL, et al. 2016. Consequences of gas flux model choice on the interpretation of metabolic balance across 15 lakes. Inland Waters. 6(4):581-592.

Eugster W, Delsontro T, Sobek S. 2011. Eddy covariance flux measurements confirm extreme $\mathrm{CH}_{4}$ emissions from a Swiss hydropower reservoir and resolve their short-term variability. Biogeosciences. 8(9):2815-2831.

Evans CD, Futter MN, Moldan F, Valinia S, Frogbrook Z, Kothawala DN. 2017. Variability in organic carbon reactivity across lake residence time and trophic gradients. Nature Geoscience. 10(11):832-835.

Fernández EJ, Peeters F, Hofmann H. 2014. Importance of the Autumn Overturn and Anoxic Conditions in the Hypolimnion for the Annual Methane Emissions from a Temperate Lake. Environmental Science \& Technology. 48(13):7297-7304. http://dx.doi.org/10.1021/es4056164

Forsyth DJ, Dryden SJ, James MR, Vincent WF. 1988. The Lake Okaro ecosystem 1. Background limnology. New Zealand Journal of Marine and Freshwater Research. 22(1):17-27. http://dx.doi.org/10.1080/00288330.1988.9516274

Gonzalez-Valencia R, Sepulveda-Jauregui A, Martinez-Cruz K, Hoyos-Santillan J, Dendooven L, Thalasso F. 2014. Methane emissions from Mexican freshwater bodies: Correlations with water pollution. Hydrobiologia. 721(1):9-22. 
Hamilton DP, McBride CG, Özkundakci D, Schallenberg M, Verburg P, de Winton M, Kelly D, Hendy C, Ye W. 2013. Effects of climate change on New Zealand lakes. In:

Goldman, C. R., Kumagai, M., Robarts RD, editor. Climate Change and Inland Waters: Impacts and Mitigation for Ecosystem and Societies: John Wiley \& Sons, Ltd.; p. 337366.

Hanson PC, Pace ML, Carpenter SR, Cole JJ, Stanley EH. 2015. Integrating Landscape Carbon Cycling : Research Needs for Resolving Organic Carbon Budgets of Lakes. Ecosystems. 18:363-375.

Hanson PC, Pollard AI, Bade DL, Predick K, Carpenter SR, Foley JA. 2004. A model of carbon evasion and sedimentation in temperate lakes. Global Change Biology. 10(8):1285-1298.

Harrell FEJ. 2015. Hmisc: Harrell miscellaneous. R package version 3.15-0. http://cran.r-project.org/package $=$ Hmisc

Holgerson MA, Raymond PA. 2016. Large contribution to inland water $\mathrm{CO}_{2}$ and $\mathrm{CH}_{4}$ emissions from very small ponds. Nature Geoscience. 9(3):222-226. http://dx.doi.org/10.1038/ngeo2654

Huttunen JT, Alm J, Liikanen A, Juutinen S, Larmola T, Hammar T, Silvola J, Martikainen PJ. 2003. Fluxes of methane, carbon dioxide and nitrous oxide in boreal lakes and potential anthropogenic effects on the aquatic greenhouse gas emissions. Chemosphere. 52(3):609-621.

Juutinen S, Rantakari M, Kortelainen P, Huttunen JT, Larmola T, Alm J, Silvola J, Martikainen PJ. 2009. Methane dynamics in different boreal lake types. Biogeosciences. 6(2):209-223. 
Kankaala P, Taipale S, Nykänen H, Jones RI. 2007. Oxidation, efflux, and isotopic fractionation of methane during autumnal turnover in a polyhumic, boreal lake. Journal of Geophysical Research. 112(2):1-7.

Klump JV, Fitzgerald S A, Waples JT. 2009. Benthic biogeochemical cycling, nutrient stoichiometry, and carbon and nitrogen mass balances in a eutrophic freshwater bay. Limnology and Oceanography. 54(3):692-712.

Kuivila KM, Murray JW, Devol A. H, Lidstrom ME, Reimers CE. 1988. Methane cycling in the sediments of Lake Washington. Limnology and Oceanography. 33(4):571-581.

Le Quéré C, Moriarty R, Andrew RM, Peters GP, Ciais P, Friedlingstein P, Jones SD, Sitch S, Tans P, Arneth A, et al. 2015. Global carbon budget 2014. Earth System Science Data. 7(1):47-85.

Lopes F, Viollier E, Thiam A, Michard G, Abril G, Groleau A, Prévot F, Carrias JF, Albéric P, Jézéquel D. 2011. Biogeochemical modelling of anaerobic vs. aerobic methane oxidation in a meromictic crater lake (Lake Pavin, France). Applied Geochemistry. 26(12):1919-1932. http://dx.doi.org/10.1016/j.apgeochem.2011.06.021 López Bellido J, Peltomaa E, Ojala A. 2011. An urban boreal lake basin as a source of $\mathrm{CO}_{2}$ and $\mathrm{CH}_{4}$. Environmental Pollution. 159(6):1649-1659.

http://dx.doi.org/10.1016/j.envpol.2011.02.042

López Bellido J, Tulonen T, Kankaala P, Ojala A. 2009. $\mathrm{CO}_{2}$ and $\mathrm{CH}_{4}$ fluxes during spring and autumn mixing periods in a boreal lake (Pääjärvi, southern Finland). Journal of Geophysical Research. 114(4):1-12. 
Maberly SC, Barker PA, Stott AW, Ville D, Mitzi M. 2013. Catchment productivity controls $\mathrm{CO}_{2}$ emissions from lakes. Nature Climate Change. 3(4):391-394. http://dx.doi.org/10.1038/nclimate1748

Marcé R, Obrador B, Morguí J-A, Lluís Riera J, López P, Armengol J. 2015. Carbonate weathering as a driver of $\mathrm{CO}_{2}$ supersaturation in lakes. Nature Geoscience. 8(2):107111. http://www.nature.com/doifinder/10.1038/ngeo2341

Martinez D, Anderson MA. 2013. Methane production and ebullition in a shallow, artificially aerated, eutrophic temperate lake (Lake Elsinore, CA). Science of Total Environment. 454-455:457-465. http://dx.doi.org/10.1016/j.scitotenv.2013.03.040 McColl RHS. 1972. Chemistry and trophic status of seven New Zealand lakes. New Zealand Journal of Marine and Freshwater Research. 6(4):399-447.

McGinnis DF, Greinert J, Artemov Y, Beaubien SE, Wüest A. 2006. Fate of rising methane bubbles in stratified waters: How much methane reaches the atmosphere? Journal of Geophysical Research. 111(9):1-15.

Messager ML, Lehner B, Grill G, Nedeva I, Schmitt O. 2016. Estimating the volume and age of water stored in global lakes using a geo-statistical approach. Nature Communication. 7:13603. https://doi.org/10.1038/ncomms13603

Moss B, Kosten S, Meerhof M, Battarbee R, Jeppesen E, Mazzeo N, Havens K, Lacerot G, Liu Z, de Meester L, et al. 2011. Allied attack: climate change and eutrophication. Inland Waters. 1(2):101-105.

Myhre G, Shindell D, Bréon F-M, Collins W, Fuglestvedt J, Huang J, Koch D, Lamarque J-F, Lee D, Mendoza B, et al. 2013. 2013: Anthropogenic and Natural Radiative Forcing. In: Stocker T.F., Qin D., Plattner G.-K., Tignor M., Allen S.K., 
Boschung J., Nauels A., Xia Y. BV and MPM, editor. Climate Change 2013 Physical Science Basis Contribution of Working Group I to the Fifth Assessment Report IPCC. Cambridge University Press, Cambridge, United Kingdom and New York, NY, USA; p. $659-740$.

Nürnberg GK. 1996. Trophic state of clear and colored, soft- and hardwater lakes with special consideration of nutrients, anoxia, phytoplankton and fish. Lake and Reservoir Management. 12(4):432-447.

Ostrovsky I, Mcginnis DF, Lapidus L, Eckert W. 2008. Quantifying gas ebullition with echosounder: The role of methane transport by bubbles in a medium-sized lake. Limnology and Oceanography Methods. 6(2):105-118.

Özkundakci D, Hamilton DP, Gibbs MM. 2011. Hypolimnetic phosphorus and nitrogen dynamics in a small, eutrophic lake with a seasonally anoxic hypolimnion. Hydrobiologia. 661(1):5-20.

Paul WJ, Hamilton DP, Gibbs MM. 2008. Low-dose alum application trialled as a management tool for internal nutrient loads in Lake Okaro, New Zealand. New Zealand Journal of Marine and Freshwater Research. 42(2):207-217. http://dx.doi.org/10.1080/00288330809509949

Quay PD, Emerson SR, Quay BM, Devol AH. 1986. The carbon cycle for Lake Washington-- a stable isotope study. Limnology and Oceanography. 31(3):596-611.

Raymond PA, Hartmann J, Lauerwald R, Sobek S, McDonald C, Hoover M, Butman D, Striegl R, Mayorga E, Humborg C, et al. 2013. Global carbon dioxide emissions from inland waters. Nature. 503(7476):355-359.

http://www.nature.com/doifinder/10.1038/nature12760 
Read JS, Hamilton DP, Jones ID, Muraoka K, Winslow L a, Kroiss R, Wu CH, Gaiser E. 2011. Derivation of lake mixing and stratification indices from high-resolution lake buoy data. Environmental Modelling \& Software. 26(11):1325-1336.

Regnier P, Friedlingstein P, Ciais P, Mackenzie FT, Gruber N, Janssens IA, Laruelle GG, Lauerwald R, Luyssaert S, Andersson AJ, et al. 2013. Anthropogenic perturbation of the carbon fluxes from land to ocean. Nature Geoscience. 6(8):597-607. http://www.nature.com/doifinder/10.1038/ngeo1830

Riera JL, Schindler JE, Kratz TK. 1999. Seasonal dynamics of carbon dioxide and methane in two clear-water lakes and two bog lakes in northern Wisconsin, U.S.A. Canadian Journal of Fisheries and Aquatic Science. 274:1-10.

Santoso AB, Hamilton DP, Hendy CH, Schipper LA. 2017. Carbon dioxide emissions and sediment organic carbon burials across a gradient of trophic state in eleven New Zealand lakes. Hydrobiologia. 795(1):341-354.

Schilder J, Bastviken D, Van Hardenbroek M, Kankaala P, Rinta P, Stötter T, Heiri O. 2013. Spatial heterogeneity and lake morphology affect diffusive greenhouse gas emission estimates of lakes. Geophysical Research Letters. 40(21):5752-5756.

Schmid M, Ostrovsky I, McGinnis DF. 2017. Role of gas ebullition in the methane budget of a deep subtropical lake: What can we learn from process-based modeling? Limnology and Oceanography. 62(6):2674-2698.

http://doi.wiley.com/10.1002/lno.10598

Schubert CJ, Diem T, Eugster W. 2012. Methane emissions from a small wind shielded lake determined by eddy covariance, flux chambers, anchored funnels, and boundary model calculations: A comparison. Environmental Science \& Technology. 46(8):45154522. 
Simmonds B, Wood SA, Özkundakci D, Hamilton DP. 2015. Phytoplankton succession and the formation of a deep chlorophyll maximum in a hypertrophic volcanic lake. Hydrobiologia. 745(1):297-312.

Smith VH, Dodds WK, Havens KE, Engstrom DR, Paerl HW, Moss B, Likens GE. 2014. Comment: Cultural eutrophication of natural lakes in the United States is real and widespread. Limnology and Oceanography. 59(6):2217-2225.

Sobek S, Durisch-Kaiser E, Zurbrügg R, Wongfun N, Wessels M, Pasche N, Wehrli B. 2009. Organic carbon burial efficiency in lake sediments controlled by oxygen exposure time and sediment source. Limnology and Oceanography. 54(6):2243-2254.

Soued C, del Giorgio PA, Maranger R. 2016. Nitrous oxide sinks and emissions in boreal aquatic networks in Quebec. Nature Geoscience. 9(2):116-120.

Striegl RG, Michmerhuizen CM. 1998. Hydrologic influence on methane and carbon dioxide dynamics at two north-central Minnesota lakes. Limnology and Oceanography. 43(7):1519-1529.

Tranvik LJ, Cole JJ, Prairie YT. 2018. The study of carbon in inland waters-from isolated ecosystems to players in the global carbon cycle. Limnology and Oceanography Letters. 3(3):41-48.

Tranvik LJ, Downing JA, Cotner JB, Loiselle SA, Striegl RG, Ballatore TJ, Dillon P, Finlay K, Fortino K, Knoll LB. 2009. Lakes and reservoirs as regulators of carbon cycling and climate. Limnology and Oceanography. 54(6_part_2):2298-2314.

Vant WN, Davies-Colley RJ, Clayton JS, Coffey BT. 1986. Macrophyte depth limits in North Island (New Zealand) lakes of differing clarity. Hydrobiologia. 137(1):55-60. 
Varadharajan C, Hemond HF. 2012. Time-series analysis of high-resolution ebullition fluxes from a stratified, freshwater lake. Journal of Geophysical Research. 117(2):1-15.

Walter KM, Zimov S a, Chanton JP, Verbyla D, Chapin FS. 2006. Methane bubbling from Siberian thaw lakes as a positive feedback to climate warming. Nature. 443(7107):71-5.

Weiss RF, Price BA. 1980. Nitrous oxide solubility in water and seawater. Marine Chemistry. 8(4):347-359.

Weiss RF. 1970. The solubility of nitrogen, oxygen and argon in water and seawater. Deep Sea Research. 17(4):721-735.

West WE, Coloso JJ, Jones SE. 2012. Effects of algal and terrestrial carbon on methane production rates and methanogen community structure in a temperate lake sediment. Freshwater Biology. 57(5):949-955.

West WE, Creamer KP, Jones SE. 2016. Productivity and depth regulate lake contributions to atmospheric methane. Limnology and Oceanography. 61:S51-S61. Weyhenmeyer GA, Kosten S, Wallin MB, Tranvik LJ, Jeppesen E, Roland F. 2015. Significant fraction of $\mathrm{CO}_{2}$ emissions from boreal lakes derived from hydrologic inorganic carbon inputs. Nature Geoscience. (November):1-6.

Wiesenburg DA, Guinasso NL. 1979. Equilibrium solubilities of methane, carbon monoxide, and hydrogen in water and sea water. Journal of Chemical \& Engineering Data. 24(4):356-360. http://pubs.acs.org/doi/abs/10.1021/je60083a006

Wik M, Thornton BF, Bastviken D, Uhlbäck J, Crill PM. 2016. Biased sampling of methane release from northern lakes : A problem for extrapolation. Geophysical Research Letters. 43: 1256-1262. 
Wilkinson GM, Buelo CD, Cole JJ, Pace ML. 2016. Exogenously produced $\mathrm{CO}_{2}$ doubles the $\mathrm{CO}_{2}$ efflux from three north temperate lakes. Geophysical Research Letters 43(5):1996-2003.

Winslow L, Read J, Woolway R, Brentrup J, Leach T, Zwart J. 2015. rLakeAnalyzer:

Package for the Analysis of Lake Physics.R package version 1.7.3. http://cran.rproject.org/package $=$ rLakeAnalyzer

Yvon-Durocher G, Jones JI, Trimmer M, Woodward G, Montoya JM. 2010. Warming alters the metabolic balance of ecosystems. Philosophical Transactions of the Royal Society of London. Series B, Biological Sciences. 365(1549):2117-2126. 
List of figures

Figure 1. Location map and the bathymetry of Lake Okaro, North Island, New Zealand. Sampling site is marked by a white circle.

Figure 2. Conceptual model of $\mathrm{CO}_{2}$ and $\mathrm{CH}_{4}$ annual budget. Ebullition (dashed box) is not accounted for in the model simulation (see text for details).

Figure 3. Measured spatiotemporal variations of temperature (A), concentrations of dissolved oxygen (B), $\mathrm{CO}_{2}(\mathrm{C})$ and $\mathrm{CH}_{4}(\mathrm{D})$ in Lake Okaro over a one-year period (September 2013 to September 2014). Solid black lines indicate calculated thermocline depth, dashed vertical lines indicate date of sampling.

Figure 4. Whole-lake storage of $\mathrm{CO}_{2}(\mathrm{~A})$ and $\mathrm{CH}_{4}(\mathrm{~B})$ in Lake Okaro and changes in the whole-lake mass storage ( $\triangle$ mass) of $\mathrm{CO}_{2}(\mathrm{C})$ and $\mathrm{CH}_{4}(\mathrm{D})$ over a one-year period (September 2013 to September 2014). Dark areas around solid mean lines indicate lower and upper 95\% confidence interval of field observations (green) and model outputs (blue). Light grey colours indicate range of bootstrapped measurement data. Negative and positive values in $\Delta$ mass indicate losses and gains of gases, respectively.

Figure 5. Rates of atmospheric flux of $\mathrm{CO}_{2}(\mathrm{~A})$, phytoplankton $\mathrm{CO}_{2}$ uptake (B), and $\mathrm{CH}_{4}$ atmospheric flux (C) and water column $\mathrm{CH}_{4}$ oxidation (D) for Lake Okaro calculated from the mass balance model. Dark areas around solid mean lines indicate lower and upper 95\% confidence interval. Light blue colours represent range of 
bootstrapped model outputs. Positive and negative values represent loss and gain of gas, respectively.

Figure 6. Greenhouse gas emission from impoundments across trophic levels. Solid line is the log-relationship between trophic levels (indicated by chlorophyll a concentration) and total emission, $R^{2}=0.16, \mathrm{p}<0.001$, with 0.95 confidence interval (light grey). Trophic levels (Trop) range: oligotrophic (oligo), mesotrophic (meso), eutrophic (eu).

Figure 7. Proportion of annual greenhouse emission rates from Lake Okaro and global lakes and impoundments across trophic state gradients. Impoundments emissions data (Downing et al. 2018) is depicted by their statistical mode. Light grey indicates $\mathrm{CH}_{4}$, dark grey indicates $\mathrm{CO}_{2}$ emission. Greenhouse emission in Lake Okaro is dominated by $\mathrm{CH}_{4}$ (light grey) and the $\mathrm{CO}_{2}$ sink is small, $-5.1 \times 10^{-3} \mathrm{~kg} \mathrm{C}-\mathrm{CO}_{2}$ eq $\mathrm{m}^{-2} \mathrm{y}^{-1}$. 
Table 1. Equations for processes in the $\mathrm{CO}_{2}$ and $\mathrm{CH}_{4}$ mass balance estimation. See Table 2 for definitions of symbols used in equations.

\begin{tabular}{|c|c|c|c|c|}
\hline Equation & $\begin{array}{l}\text { Eq. } \\
\text { No. }\end{array}$ & Units & Process definition & Source \\
\hline$C_{s t r g}=\sum_{i=1}^{z} \frac{C_{(i)} d V_{(i)}}{A_{(i)}}$ & (1) & $\mathrm{mmol} \mathrm{m}{ }^{-2}$ & Whole-lake water column gas storage & 1 \\
\hline$\Delta C_{s t r g}=\frac{d C_{s t r g}}{d t}$ & (2) & $\mathrm{mmol} \mathrm{m} \mathrm{m}^{-2} \mathrm{~d}^{-1}$ & $\begin{array}{l}\text { Observed gas mass change over the } \\
\text { sampling period }\end{array}$ & \\
\hline$\frac{d C H_{4} \text { strg }}{d t}=J_{C H 4}-R w_{o x i}-F_{C H 4}$ & (3) & $\mathrm{mmol} \mathrm{m} \mathrm{m}^{-2} \mathrm{~d}^{-1}$ & $\begin{array}{l}\mathrm{CH}_{4} \text { mass balance model over the } \\
\text { sampling period }\end{array}$ & \\
\hline$\frac{d \mathrm{CO}_{2_{s t r g}}}{d t}=J_{C O 2}+R w_{o x i}+C h l_{l a b}+D O C_{p x}-U p-F_{C O 2}$ & (4) & $\mathrm{mmol} \mathrm{m} \mathrm{m}^{-2} \mathrm{~d}^{-1}$ & $\begin{array}{l}\mathrm{CO}_{2} \text { mass balance model over the } \\
\text { sampling period }\end{array}$ & \\
\hline$R w_{o x i}=\sum_{i=1}^{z} \frac{K_{C H 4-O 2} C H_{4(i)} O_{2} d V_{(i)}}{O_{2 s o l} A_{(i)}} e^{Q 10(t e m p-20) / 10}$ & (5) & $\mathrm{mmol} \mathrm{m} \mathrm{m}^{-2} \mathrm{~d}^{-1}$ & $\begin{array}{l}\text { Whole lake } \mathrm{CH}_{4} \text { oxidation flux with } \\
\text { Arrhenius temperature (temp) adjustment }\end{array}$ & 2 \\
\hline$U p=\frac{10.3 C h l^{1.9} V_{\text {surf }}}{12.01 \mathrm{~A}}(1-r a)$ & (6) & $\mathrm{mmol} \mathrm{m} \mathrm{m}^{-2} \mathrm{~d}^{-1}$ & Phytoplankton $\mathrm{CO}_{2}$ uptake & 3 \\
\hline${ }^{\prime} C h l_{l a b}=C h l r_{c h l}$ & (7) & $\mathrm{mmol} \mathrm{m} \mathrm{m}^{-2} \mathrm{~d}^{-1}$ & Phytoplankton decomposition & \\
\hline$F_{\text {gas }}=\operatorname{corr}_{k} k_{\text {gas }}\left(C_{\text {surf }}-C_{a t m}\right)$ & (8) & $\mathrm{mmol} \mathrm{m} \mathrm{m}^{-2} \mathrm{~d}^{-1}$ & Atmospheric gas flux & \\
\hline
\end{tabular}

Sources: ${ }^{1}$ Striegl and Michmerhuizen (1998), ${ }^{2}$ Lopes et al. (2011), ${ }^{3}$ delGiorgio and Peters (1993). 
Table 2. Parameters used for $\mathrm{CO}_{2}$ and $\mathrm{CH}_{4}$ mass balance calculations.

\begin{tabular}{|c|c|c|c|c|}
\hline Symbol & Description & Units & Value & Source \\
\hline$\overline{C_{(i)}}$ & $\begin{array}{l}\text { Concentration of the dissolved gas in } \\
\text { layer (i) }\end{array}$ & $\mu \mathrm{M}$ & & \\
\hline$V_{(i)}$ & Lake volume in layer (i) & $\mathrm{m}^{3}$ & & \\
\hline$V_{\text {surf }}$ & Lake volume of 0 to $2 \mathrm{~m}$ surface layer & $\mathrm{m}^{3}$ & & \\
\hline$A_{(i)}$ & Lake surface area in layer (i) & $\mathrm{m}^{2}$ & & \\
\hline$i$ & Water column layer & & & \\
\hline$n$ & Number of samples & & & \\
\hline$t$ & Date of sampling & & & \\
\hline$z$ & Lake depth & $\mathrm{m}$ & & \\
\hline$C h l$ & Chlorophyll $a$ concentration & $\mu \mathrm{g} \mathrm{L}^{-1}$ & & \\
\hline$k_{\text {gas }}$ & Gas exchange coefficient & $\mathrm{m} \mathrm{d}^{-1}$ & & 4 \\
\hline$C_{\text {surf }}$ & $\begin{array}{l}\text { Dissolved gas concentration at the air- } \\
\text { water interface }\end{array}$ & $\mu \mathrm{M}$ & & \\
\hline$C_{a t m}$ & $\begin{array}{l}\text { Gas solubility concentration calculated } \\
\text { from atmospheric molar fraction } \\
\text { concentration }\end{array}$ & $\mu \mathrm{M}$ & & 5,6 \\
\hline$D O C$ & Dissolved organic carbon concentration & $\mu \mathrm{M}$ & & \\
\hline$p x$ & Photo oxidation of DOC & $\mathrm{d}^{-1}$ & 0.005 & 7 \\
\hline $\mathrm{O}_{2}$ & Dissolved oxygen concentration & $\mu \mathrm{M}$ & & \\
\hline$O_{2 s o l}$ & Oxygen solubility & $\mu \mathrm{M}$ & & 8 \\
\hline$J_{C O 2}$ & $\begin{array}{l}\text { Diffusive flux of } \mathrm{CO}_{2} \text { from the sediment } \\
\text { to water column }\end{array}$ & $\mathrm{mmol} \mathrm{m} \mathrm{m}^{-2} \mathrm{~d}^{-1}$ & 3.81 & 9 \\
\hline$J_{C H 4}$ & $\begin{array}{l}\text { Diffusive flux of } \mathrm{CH}_{4} \text { from the sediment } \\
\text { to water column }\end{array}$ & $\mathrm{mmol} \mathrm{m} \mathrm{m}^{-2} \mathrm{~d}^{-1}$ & 2.54 & 9 \\
\hline \multicolumn{5}{|c|}{ Parameters used for optimization routine } \\
\hline $\operatorname{corr}_{k}$ & $\begin{array}{l}\text { Correction factor for gas exchange } \\
\text { coefficient }\end{array}$ & & $0.1-6.0$ & 10 \\
\hline $\mathrm{KCH}_{4-\mathrm{O} 2}$ & Aerobic $\mathrm{CH}_{4}$ oxidation constant & $\mathrm{d}^{-1}$ & $0.001-1.0$ & 11 \\
\hline$r a$ & $\begin{array}{l}\text { Proportion of phytoplankton production } \\
\text { that is respired }\end{array}$ & $d^{-1}$ & $0.5-0.99$ & $\begin{array}{c}7,12 \\
13\end{array}$ \\
\hline$r_{C h l}$ & Mineralization rate of dead phytoplankton & $\mathrm{d}^{-1}$ & $0.001-0.7$ & 14 \\
\hline
\end{tabular}


Sources: ${ }^{4}$ Cole and Caraco (1998), ${ }^{5}$ Weiss and Price (1980), ${ }^{6}$ Wiesenburg and Guinasso (1979),

${ }^{7}$ Hanson et al. (2004), ${ }^{8}$ Weiss (1970), ${ }^{9}$ Santoso et al. (2017), ${ }^{11}$ Dugan et al. (2016), ${ }^{11}$ Bastviken (2009)

and reference therein, ${ }^{12}$ Cole et al. (2002), ${ }^{13}$ Quay et al. (1986), ${ }^{14}$ Connolly and Coffin (1991) 
Table 3. Estimated processes contributed to $\mathrm{CO}_{2}$ and $\mathrm{CH}_{4}$ whole-lake storage based on the mass balance model output over a one-year period in Lake Okaro. Values are given in $\mathrm{mmol} \mathrm{m}^{-2} \mathrm{y}^{-1}$. Numbers in parentheses indicate lower and upper $95 \%$ of confidence interval. Negative and positive values represent losses and gains of gases, respectively. NA is not available due to the nature of the process.

\begin{tabular}{lcc}
\hline Modeled process & $\mathbf{C O}_{2}$ & $\mathbf{C H}_{4}$ \\
\hline Sediment flux & 1430.2 & 946.0 \\
CH4 oxidation & $(1214.2-1646.2)$ & $(801.8-1090.2)$ \\
& 508.5 & -508.5 \\
Phytoplankton uptake & $(385.6-631.4)$ & $(385.6-631.4)$ \\
& -4950.4 & NA \\
Phytoplankton decomposition & 2974.4 & NA \\
DOC photo-oxidation & $(2551.2-3397.5)$ & NA \\
Atmospheric flux & 175.0 & -545.2 \\
& $(148.9-201.2)$ & $(-461.8--673.6)$ \\
\hline
\end{tabular}


Figure 1.

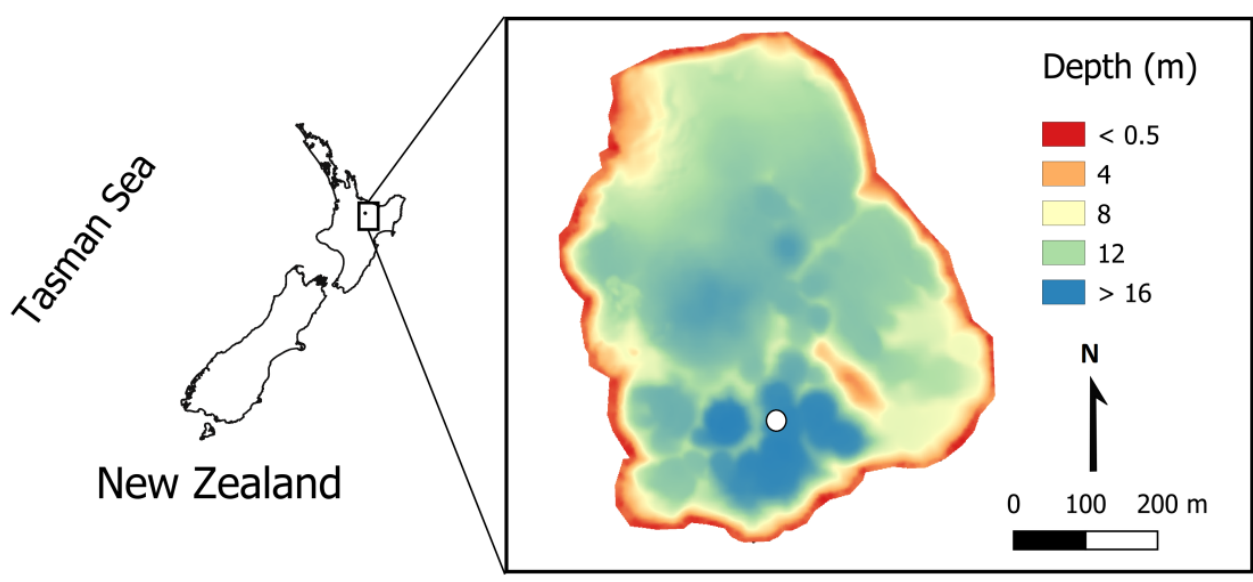

$0 \quad 1000$ 2000 km 
Figure 2.

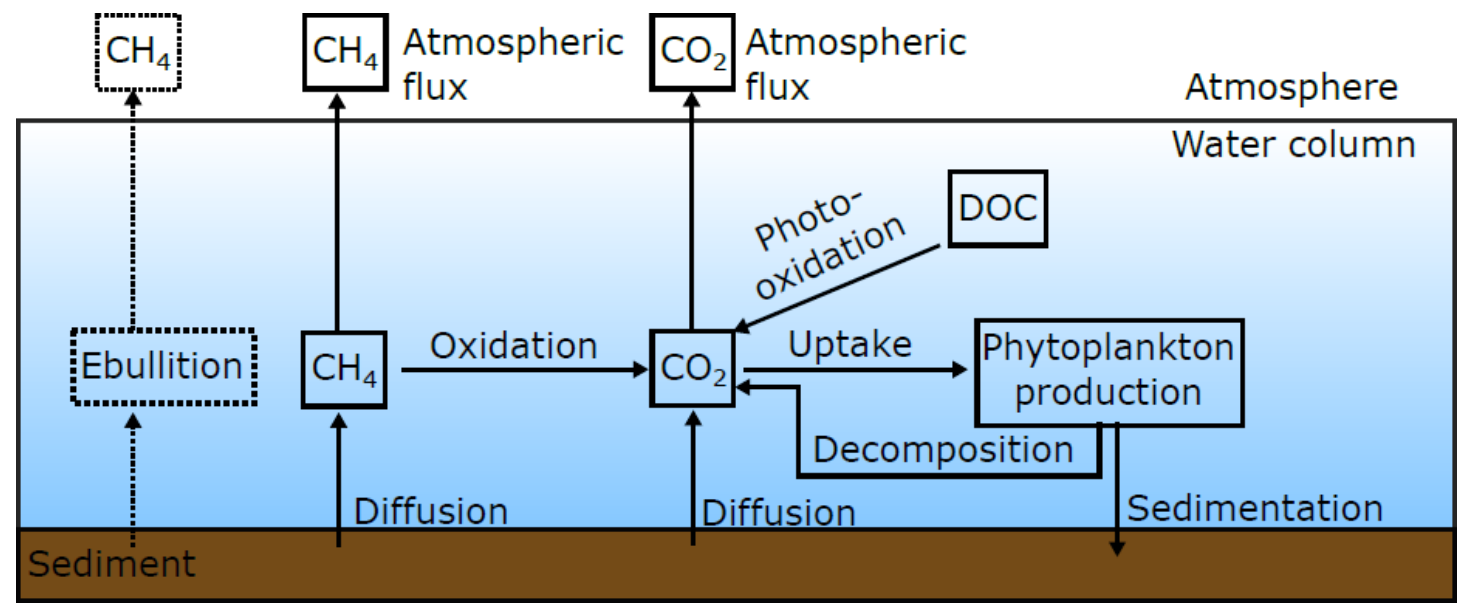


Figure 3.
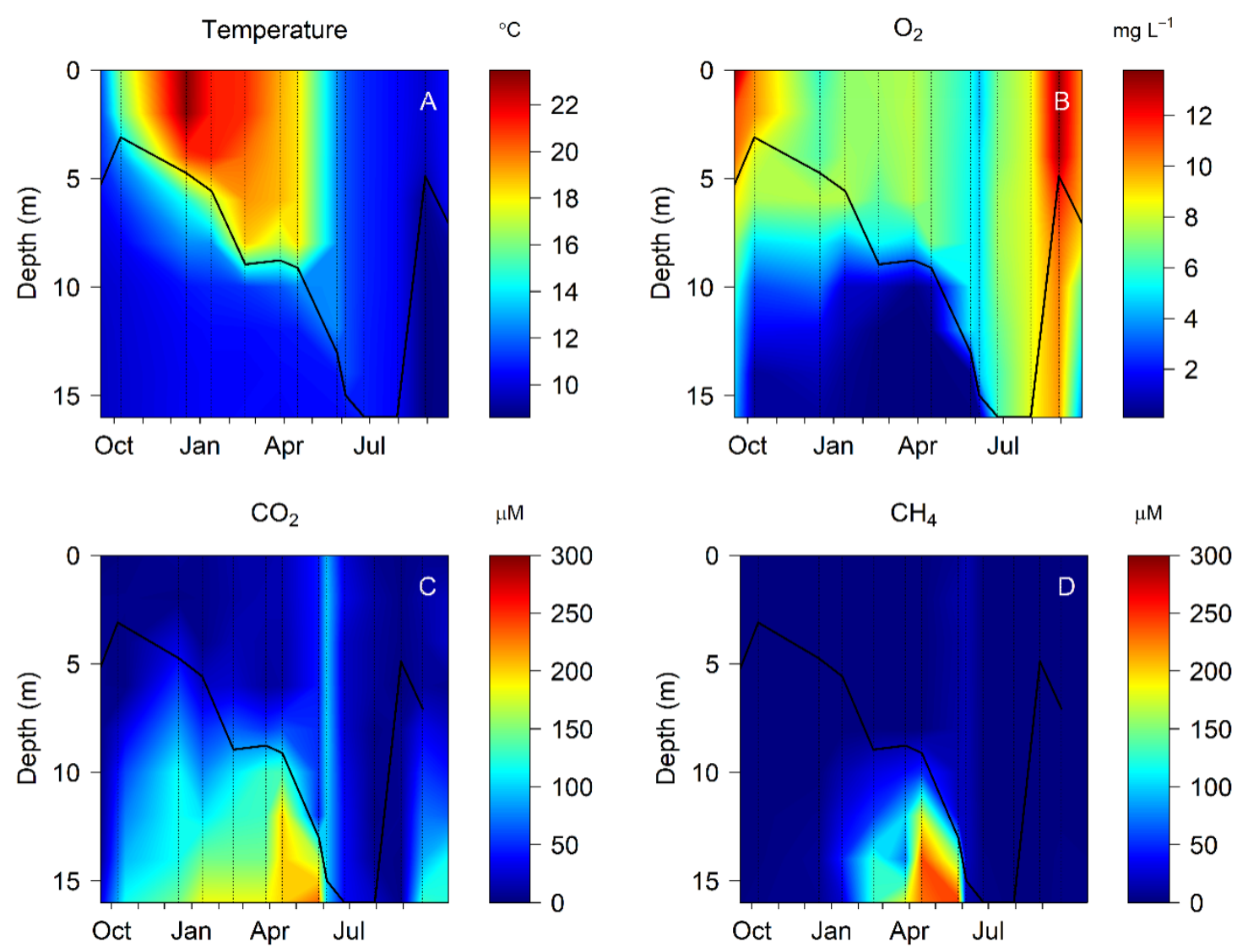
Figure 4.
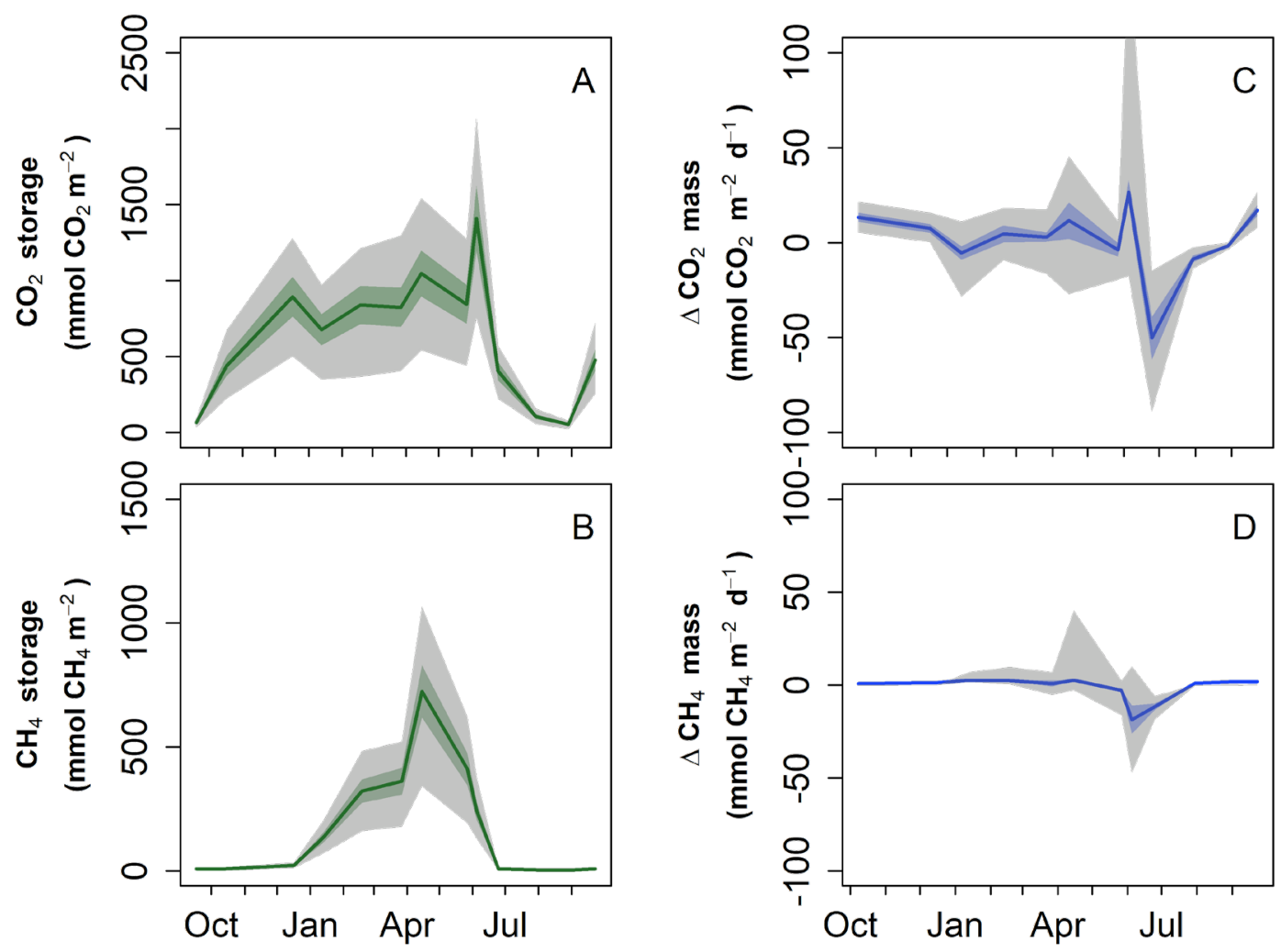
Figure 5.
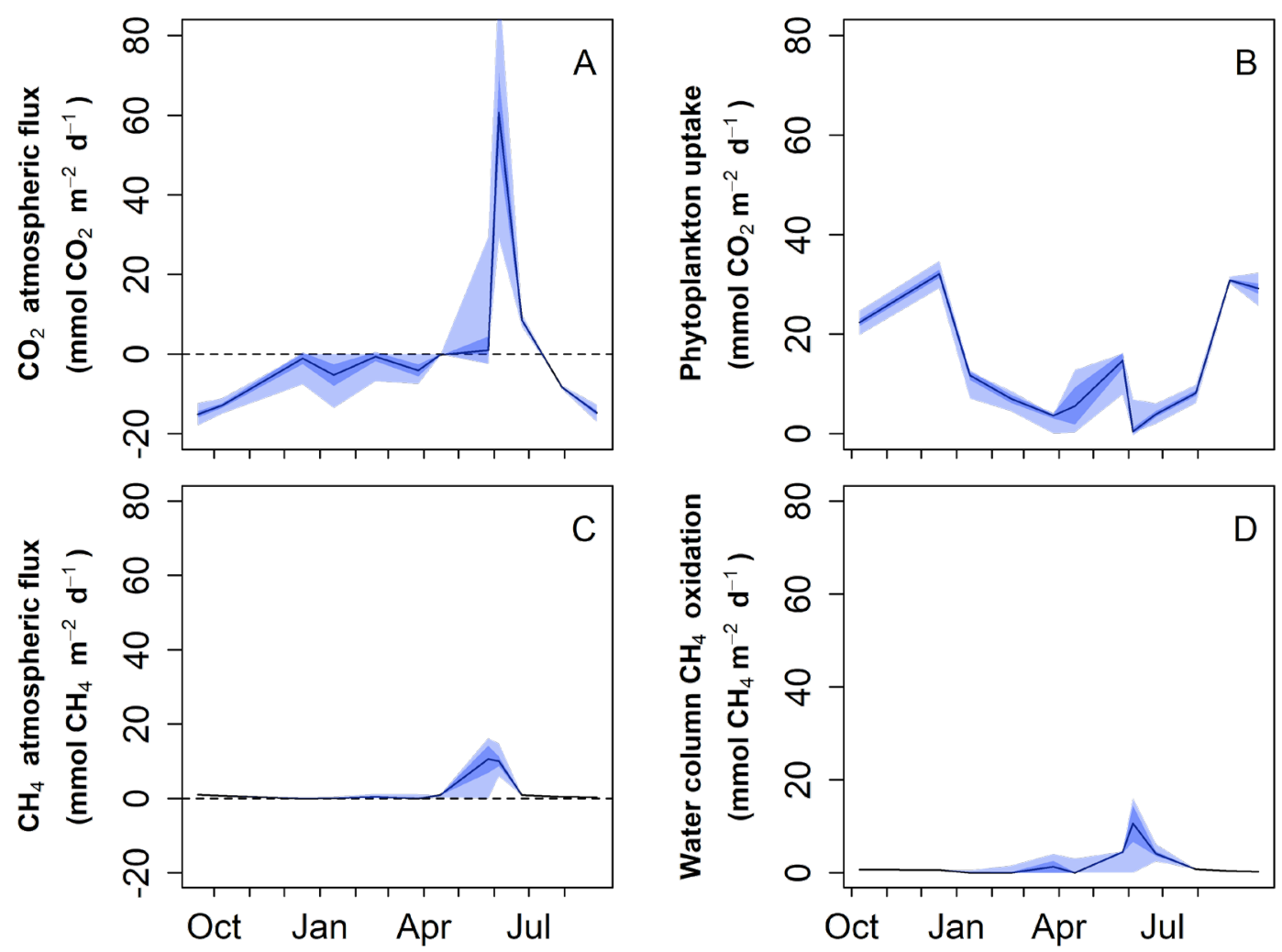
Figure 6.

Trop - eu - meso - oligo

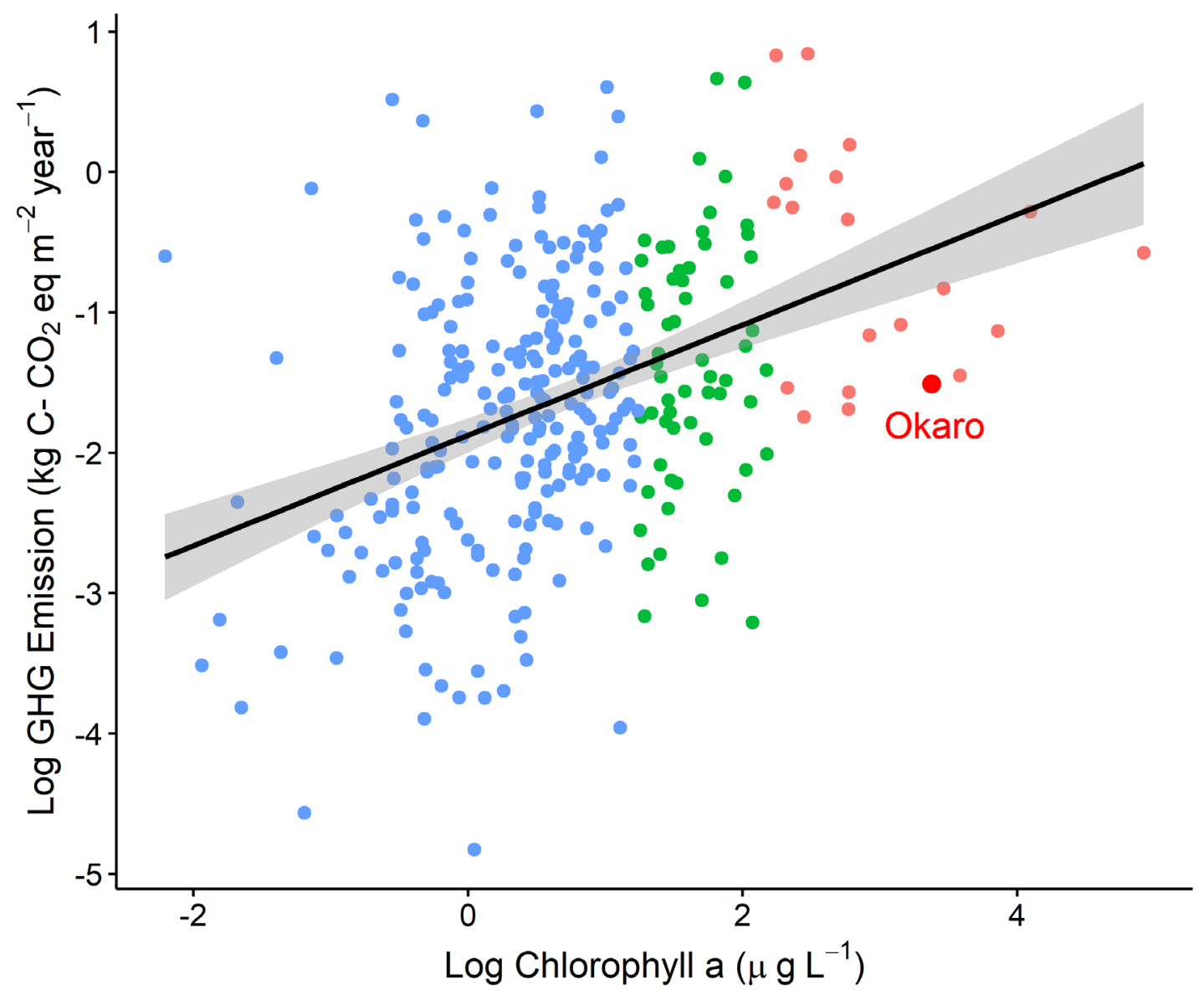


Figure 7.

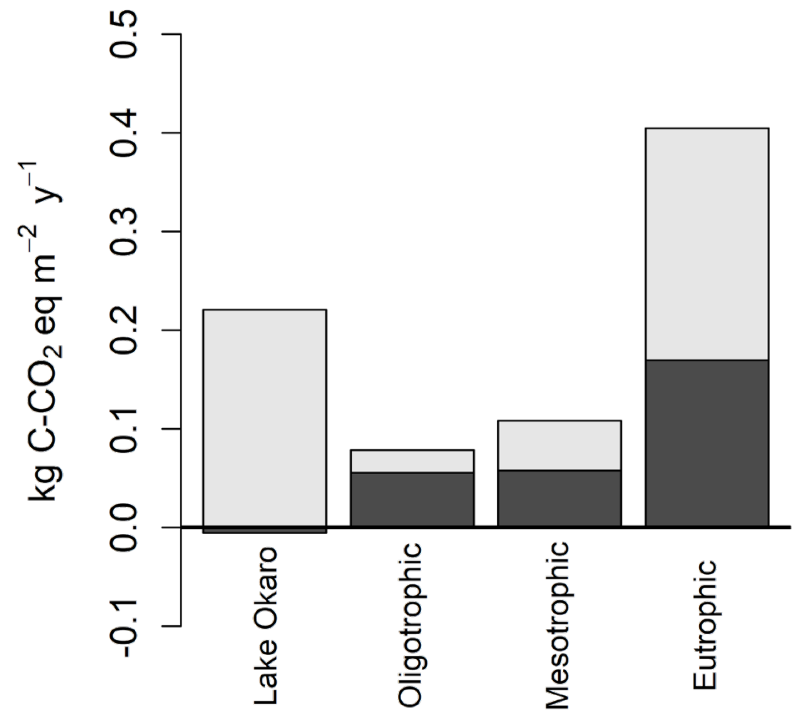

